\title{
THE SYSTEM OF THE FOOD SECURITY CRITERIA IN ACCORDANCE WITH THE MEASUREMENTS OF THE SDGs-2030
}

\author{
Olena Kotykova ${ }^{1}$, Mykola Babych ${ }^{2}$, Anna Yahodzinska ${ }^{3}$ \\ ${ }^{1}$ Doctor of Economic Sciences, Professor, Mykolaiv National Agrarian University, Mykolaiv, Ukraine, Phone \\ Number+38 (099) 29303 63, Email Address eikotikova7@gmail.com \\ ${ }^{2}$ Doctor of Economic Sciences, Associate Professor, Admiral Makarov National University of Shipbuilding, \\ Mykolaiv, Ukraine, \\ Phone Number+38(067) 51800 98,Email Address babychnnn@gmail.com \\ ${ }^{3}$ Master, Postgraduate Student, Mykolaiv National Agrarian University, Mykolaiv, Ukraine. \\ Phone Number+38(096) 05292 63, Email Address yahodzinska19@gmail.com
}

Received 2001 2020; Accepted 31082020

\begin{abstract}
Effective management of any system is impossible without a clear definition of its elements, hierarchical levels and desired performance indicators. Considering this problem in the context of food security management, the authors set out to create a system of food security criteria at different hierarchical levels. In this work, the basis of theoretical and methodological research is based on two principles: (1) the principle of interdependence of indicators, criteria and content of food security; (2) the principle of compliance of food security criteria with CSD2030 measurements and management levels. As a result, a critical analysis of scientists' approaches to the definition of the system of food security criteria is carried out. The expediency of the methodological approach, in which the essence of the concept is formed, based on the defined criteria for achieving food security, is substantiated. The author's vision of essential content of categories is offered: criterion, component and indicator of food security. Determinants of each hierarchical level are established as criteria for achieving food security. The results obtained are of great practical importance in shaping national and regional food security policies (programs) on a sustainable development basis.
\end{abstract}

Keywords: food security, criteria, indicators, global level, national level, regional level, level of household and individual.

JEL Codes: B41, L51, Q0.

\section{Introduction}

The problem of defining food safety criteria and identifying the subjects of management decisions that affect the effectiveness of the food supply system is complex. Despite the fact that approaches, both theoretical and methodological and methodological, to assessing the compliance of the food system with the criteria of sustainability are studied by both domestic experts and reputable international researchers, the task of assessing food security, and thus developing measures, tools and methods to improve it remain open.

Moreover, such studies are necessary in the face of constant environmental changes and those that have already exceeded the planet's ability to self-heal (Campbell et al., 2017). The paradox is that human activities aimed at ensuring food security have led to completely different consequences: soil degradation, a slowdown in the reproduction of natural resources (Ranganathan et al., 2016), an increase in consumption with a general deterioration in the quality of food and nutrition.

Copyright (C) 2020. Published by Vytautas Magnus University. This is an open access article distributed under the terms of the Creative Commons Attribution Non-Commercial 4.0 (CC BY-NC 4.0) license, which permits unrestricted use, distribution, and reproduction in any medium provided the original author and source are credited. The material cannot be used for commercial purposes. 
In such conditions, it is extremely important to develop an acceptable system of food security criteria, which will determine the objectives and goals of food programs of countries and regions, as well as directions and measures for their implementation (Béné et al., 2019).

The work of many scientists are dedicated to the research of the problem of establishing the dominant criteria that forms the framework for ensuring food security. In particular, the criteria for food security at the national level are investigated by Grishova (2014), Strashinska (2012), Kundeeva (2013), Novikov (2012). A system of criteria at the regional level is studied by Kundeeva (2013), Artimonova (2016), Kotykova (2019) etc. The level of households and individual in terms of establishing the essential criteria for food security is investigated by Kundeeva (2013), Armatya Sen (1984), Mostenska (2015) and others.

The approaches of foreign scientists in solving this issue can be grouped in several directions.

1. The governance reforms of Common Food Policy.

Olivier De Schutter et al. (2020) argues that the EU's food security management system is vulnerable both in terms of the functioning and interconnection of agriculture and the food industry, and in terms of levels of government. Researchers see a way out of this situation in the formation and development of a special structure "Common Food Policy".

2. The relationship between the Common Agricultural Policy (CAP) and food security.

In the food supply system, agriculture is still a defining component. For most countries, agriculture has a significant weight in GDP and a high employment rate. This means that sustainable agriculture continues to have a major impact on the food supply and quality of life of the population (Johan van Rooyen, Howard Sigwele et al., 1998).

Based on a conceptual framework that links the policy cycle approach to transition theories, Francesca Galli et al. (2020) (1) assess the evolution of policy cycles of the CAP to highlight how the food and nutrition concepts have evolved and been reframed throughout the five phases of the CAP, (2) map and classify available policy instruments to assess potential synergies and gaps in view of their reorganization and (3) indicate and discuss strategic tools for sustainable food policies.

An inductive analysis of frameworks suggests that they can be divided into six contradictory and overlapping subframes (Jeroen J. L. Candel et al., 2014): "(1) the productionist frame, (2) the environmental frame, (3) the development frame, (4) the free trade frame, (5) the regional frame, and (6) the food sovereignty frame". Each of these frames was invoked by a specific group of stakeholders, whereby the productionist and environmental frames were deployed most often. The European Obviously, at the next stage of building and implementing the CAP policy, it is necessary to take into account the level of influence of the CAP not only on European, but also on global food security.

However, it should be borne in mind that food security cannot be ensured only through internal reserves: through the country's agriculture. The experience of some countries shows that this approach does not solve the problem of food security (Johan van Rooyen, Howard Sigwele et al., 1998).

3. Economic and physical availability of food at different levels, financial security and productivity.

This approach, according to Johan van Rooyen, Howard Sigwele et al. (1998) contributes to the reduction of poverty and increased economic growth, which is an important part of the food security strategy.

The third approach is based on household consumption and expenditures surveys (HCESs). This approach has disadvantages in terms of statistical bias, but HCESs have a number of distinct advantages when examining household diets in relation to their costs (John L. Fiedler, 2013). Such studies are also conducted in Ukraine, and it is thanks to them that it is possible to determine the level of food security of a household depending on various factors: the composition of the household, place of residence, income level, etc. 
Thus, even a brief overview of the problem allows us to conclude that there are many different approaches to determining the key criteria for food security. Questions about criteria and factors, as well as the interpretation of some categories, still trumpet answers (Béné et al., 2019). At the same time, there are significant differences in the views of scientists in the methodological sense of: the dominant criteria that form the framework for ensuring food security; the essence and substitution of the concepts of "constituents", "criteria" and "indicators" of food security; the appropriateness of differentiating the hierarchical levels of food security and setting criteria for them.

The problem of the study. The impossibility of an objective assessment of food security and the formation of an effective state, regional and local food security policy due to the lack of a unified system of the food security criteria in accordance with the measurements of the SDGs-2030.

The purpose of the study. Conduct a critical analysis of scientists' approaches to the definition of the system of food security criteria and develop proposals for the formation the system of food security with the measurements of the SDGs-2030 criteria based on identified problems.

The object of the study is a system of food security criteria.

The research subject includes the methodological approach to the formation the system of food security with the measurements of the SDG-2030 criteria.

Research methodology. There are different methodological approaches to managing food security. In this work, the basis of theoretical and methodological research is based on two principles: (1) the principle of interdependence of indicators, criteria and content of food security; (2) the principle of compliance of food security criteria with SDGs-2030 measurements and management levels.

From a methodological point of view, the construction of a food security metrics system should occur through defining the criteria for the functioning of the system, since such an approach ensures interconnection and interdependence between the nature, objectives and monitoring of food security at any level. In turn, the criteria define the essence of the concept of "food security". In this study, the category of food security is defined as the socio-economic and environmental state of development that ensures the constant physical, economic and social access of people to safe and nutritious food through the use of adequate mechanisms at different hierarchical levels. The division of food security by level is an important component of effective governance of the system as a whole: global food security requires the efforts of the entire world community, national level - prudent state policy, regional level is provided by local authorities and local food producers, and the level of household and individual security characteristics of a particular family and person. Thus, if at national and regional level, a person is an object of food security, then at the household and individual level, it is already a subject, requiring the use of different tools and mechanisms to achieve the desired state of food security.

\section{Research results and discussion}

There are different points of view of scientists regarding the procedure of forming a system of criteria, norms and indicators of food security.

From a methodological point of view, the construction of a system of food security indicators should take place through the definition of the criteria for functioning of the system, because such approach ensures the interconnection and interdependence between the nature, objectives and monitoring of food security at any level.

In turn, the criteria are determined by the essence of the concept of "food security". Previously, a system of existing concepts for the interpretation of the concept of "food security" was formed and a definition of the term was given, on the basis of which the criteria, norms and indicators of food security will be considered.

Global level. At the global level, achieving the food security criteria is determined by the objectives of the CSB-2030. To a greater extent this refers to the achievement of the SDG 2, which 
requires attention to all four dimensions of food security and nutrition as defined in the World Food Summit of 1996 (Figure 1).

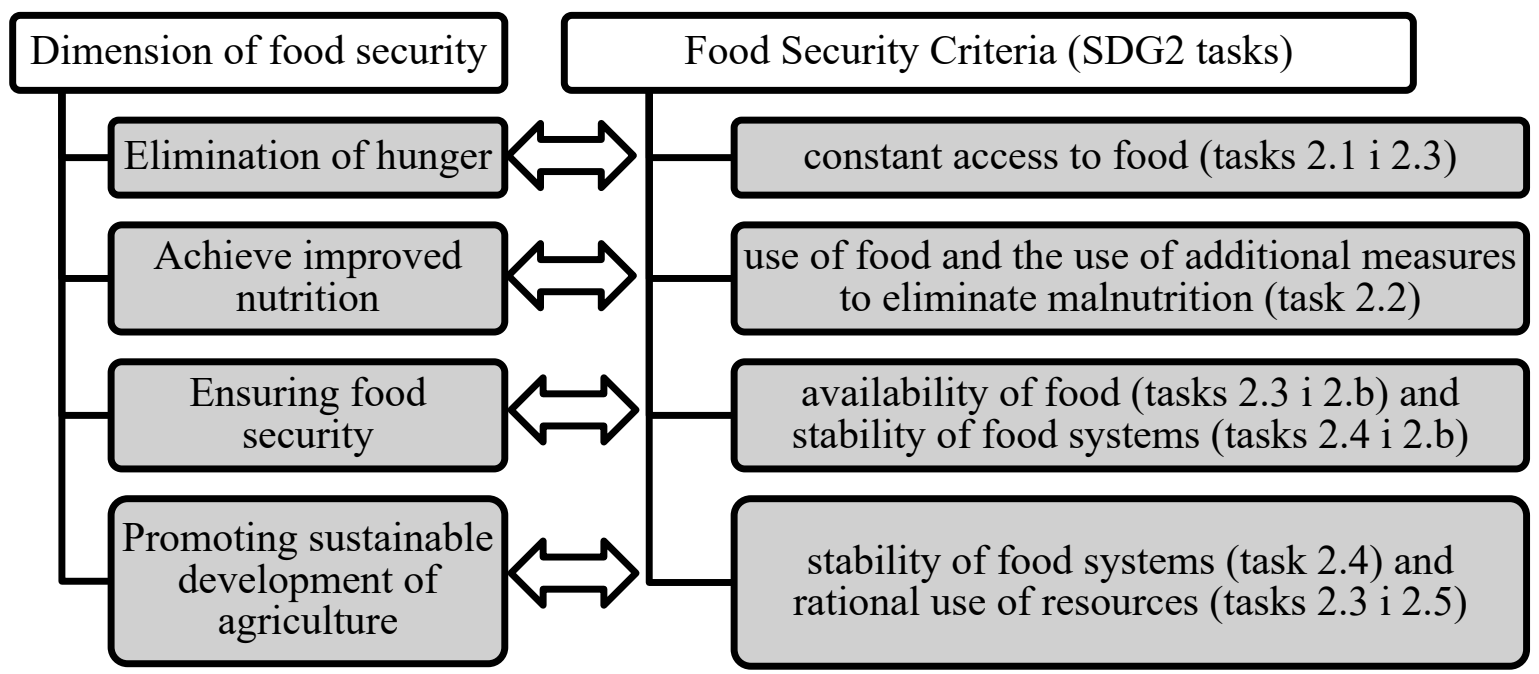

Figure 1. Relationship between the tasks of the SDG2 and the dimensions of food security (FAO, 2016)

It should be noted that the defined criteria have no subordination in achieving specific goals: depending on the specific conditions, the implementation of one and the same task can have a multiplicative effect as a result of the chain reaction and the synergy of interaction and mutual influence. For example, in a situation where livelihoods for people suffering from food insecurity are agriculture, agricultural productivity growth and small-scale food incomes (task 2.3), it will also contribute to improving access to food (task 2.1) and at the same time it will improve agricultural sustainability (task 2.4). Doubling the productivity and income of small food producers (task 2.3) may not be enough to eliminate hunger and ensure sufficient food availability. In other words, the progress in solving each of these tasks will be evaluated in combination with the results obtained in the process of implementing others. Achievement of the SDG 2 is possible only if these tasks are fulfilled.

Moreover, progress in the tasks of the SDG 2 will depend on the achievement of defined criteria in other areas of the Agenda for the period up to 2030. Therefore, it is obvious that in the process of development of a food security policy and its implementation programs these interactions and possible compromises should be taken into account.

FAO experts developed criteria for assessing the status of international food security in two dimensions: global cereal stocks, up to the next harvest, and world average grain production per capita.

National level. Ukrainian scientists have different points of view regarding food security criteria at the national level. In particular, Grishova I. Yu. and Kryukov I. O. (2014) determine the following criteria: high level of population food supply; strategic opportunities for increasing export potential; formation of an effective mechanism for the protection of national agro-industrial producers; ensuring the price accessibility and the correct ratio of food in the consumer basket for the population of the country; increasing the capacity of the internal food market; food independence of the national market (at least 75\%); high quality and security of food, preservation of the health of the population and future generations; the existence of an effective system of economic support for the processes of reproduction and consumption of food; stability of food supply; dynamic and sustainable development of national agro-industrial production. Agreeing with the principal aspects of the main features of ensuring food security proposed by these scientists, it was considered as expedient to 
include some of them not according to criteria, but tasks, in particular: strategic possibilities of increasing export potential; formation of an effective mechanism for the protection of national agroindustrial producers; ensuring the price availability and the correct ratio of food in the consumer basket for the population of the country. In fact, these are the goals that will contribute to achieving the appropriate levels of criteria for constant access to food, its availability and the stability of the food system.

Strashinska N.V. and Gretska G.A. (2012) define the following the criteria for food independence criteria: the criterion of the adequacy of food consumption (the energy value of a daily diet per capita should be not less than 2,5 thousand kcal); criterion of availability of food consumption (food expenses should not exceed $60 \%$ of the family budget); the share of food imports on the domestic agro-food market. The defined criteria are fully consistent with the objectives of food security monitoring, but not all tasks can achieve the appropriate level of food security.

Kundeeva O. I. (2013) defines the following criteria for assessing national food security of the country (macro level): gross national output of agricultural products, raw materials and food (the level of physical availability of food); the level of inflation in the country; the growth rate of personal income; level of income differentiation of the population of the country; compliance with restrictions on the presence of substances harmful to health in products; the level of dependence of food supply of the country and resource supply of the agro-industrial complex on import deliveries; the size of strategic and operational food stocks in accordance with regulatory requirements. The partially given criteria can be considered as meeting the objectives of the national food security assessment; the rest - should be considered as development indicators.

Novikov E. Yu. highlights four criteria for achieving food security (2012): sufficient food; availability of food; the required quantity and quality of food; the stability of food supplies.

The fundamental international act regulating the issue of international food security is the Rome Declaration on World Food Security (1996) that includes a comprehensive strategy to overcome the global food crisis at the global and regional levels. It expresses two main theses of the strategic directions of providing international food security with the help of national systems of regulation of agrarian production:

1) compliance with sustainable policies and practices in food, agriculture, fishing, forestry and rural development in territories with high or low potential, i.e. mobilization and maximum utilization of resources and national agroeconomic potential of each state, which ultimately contributes to increasing global food resources;

2) creating the conditions for food, agricultural and general trade policies in order to lead to food security for all through an honest and market-oriented world trade system (Artimonova, 2016).

Thus, the implementation of an effective agro-trade policy of the state should be considered as the defining criterion of food security at the national level.

Regional level. The overwhelming majority of scholars in the formation of regional-level criteria tend to increase their number in relation to the national level. At the same time, there remains the problem of delineating the criteria and indicators for assessing food security at the regional level.

So, Kundeeva G. O. (2013) believes that, at the meso-level (at the regional level), food security should take into account the economic potential, conditions and specialization of agricultural production. Accordingly, food security at the regional level is evaluated according to the following criteria: the level of consumption of the main types of food in the region per capita; income level of the population of the region per capita; gross output of agricultural products, raw materials and food in the region; the price level of the regional food market for both domestic and imported products; the volume of deliveries of agricultural products and food from other regions and into other regions; the volume of export-import deliveries of agricultural products and food; the level of quality food supply (component and energy content). In fact, the author defines indicators for assessing food security at the regional level on the criteria for self-sufficiency of food and its physical availability. 
According to Artimonova I. V. (2016) the conditions of global and local crisis phenomena, which nowadays have a systemic and devastating impact on the economic processes of the region, the state and the world economy, and because of the existence of a number of large-scale threats to regional food security, there is a need to manage the regional food security. At the same time, this management process involves the use of effective instruments of state influence on the food supply of the region. At the same time, the food safety of the region is based on the ability of the system to provide various social groups of the population of the area with food consistently and evenly in the amount of consumption that meets scientific standards of healthy eating.

Consequently, forming of sustainable food systems should be considered as the determining criterion for food security at the regional level. The main components of the latter are the construction of short supply chains for strengthening local food systems, as well as reducing food and food waste.

Level of household and individual. The issue of food security at the household level became relevant when it was found that adequacy at the aggregated level does not ensure adequate nutrition in households or at individual level. That is why the United Nations Special Committee proposed the definition of food security through the availability of food for households. "Food security is provided when households have access to safe food in quantities that is necessary to ensure a healthy lifestyle for all its members (adequate in terms of quality, quantity and cultural traditions) and when there is no excessive risk of losing access to it" (Initiative of the United Nations Ad Hoc Committee, 2017).

At the same time, at the level of the household and the individual, it is much more difficult to determine the principal approaches of scientists to the system of food safety criteria because: firstly, not all researchers allocate such levels or do not pay attention to them, focusing on the first three; and secondly, there is a group of scientists who combine the last two levels, because they do not see the fundamental difference between them in terms of the criterion of their assessment; Thirdly, the problem of delimiting the criteria and indicators of food security assessment at the last two levels is methodologically much more complex, compared to global, national and regional levels.

Due to the first thesis, the following was noted. The winner of the Nobel Prize Armatya Sen (1984) showed that food security cannot be determined only at the national or regional levels. Even if the country is an exporter of food, some very sensitive, low-income groups may be suffering from malnutrition. Perhaps they are not able to produce their own products or are not integrated into certain social associations, such as the family.

Mostenska T. G. (2015) notes that household food security is provided when households have access to safe and healthy food for all its members and there is no excessive risk of loss of such access.

Kundeeva G. O. (2013) combines the level of households and the level of the individual in a single micro level of food security (this is an opportunity to meet their own human needs in the diet for productive activities). According to the opinion of the author, based, first of all, on the social function of the individual, it is advisable to consider this level of food security in relation to a certain community (family), that is, at the household level. The author submits the following criteria for the assessment of food security at the micro level: the level of physical availability of food; the level of economic availability of food; a measure of satisfaction of physiological needs in the components and energy content of the diet. In fact, the author narrows down the system of criteria and reduces them all to one - the level of food security.

Scientists often combine the last two levels, because in the household (family) personal preferences have less impact than the need to provide family members with health, and the vast majority of individuals are members of households. Moreover, this will be not only the food set, but also the way of life of the family as a whole. Thus, it was decided to take social and psychological assessments of consumer behavior of households as priority.

The last two levels of food security can be considered identical if the household consists of one person, then these levels are just the same, but in all other cases (and such overwhelming majority was mentioned earlier), these levels should be distinguished. 
The simplest example - vegans - people who refuse any products whose origin is associated with the killing or exploitation of animals (even banning honey and gelatine), which unambiguously excludes from the diet of such a population the consumption of animal proteins and any food, containing raw material of animal origin. Thus, for this group of consumers, ensuring food security by the category of physical accessibility in the classical format will never be achieved for the number of calories consumed in animal origin.

On the other hand, the athlete always "will not eat" calories of vegetable origin, because the basis of his diet are proteins of animal origin. That is, there are completely different variations in the human diet, which for various reasons (vegan, athlete, chronically ill, model, etc.) adheres to a certain diet that determines the composition and structure of the diet. It should be also taken into account the variability in the time of personal preferences that are associated with certain beliefs or human desires in a particular period of his life: the athlete can leave professional sport, model - podiums, vegan change beliefs.

There are many different modifications of the behavior of each individual who will determine its diet (those determined by the level of food availability wasn't taken into account) and all of them are in a constant process of modification, therefore, to determine the level of food security of the individual is possible only through the degree of satisfaction personal needs of a person at a specific moment in time. The fundamental difference of this level from all others is the fact that criteria and level of food supply at all levels, except for the latter, can be defined by an appropriate method with a sufficiently high degree of certainty: authorized state and local authorities, scientists and researchers, legal bodies or individuals; while one can estimate the level of food security of the individual only by the person himself, according to specific indicators, important, perhaps only for its personally.

Therefore, the basic criterion for ensuring food security at the household level should be the provision of health of its members, and at the individual level, the satisfaction of personal needs. Moreover, both in the household and in the state are interested to ensure the health of household members, but satisfaction of personal needs can lead to the conflict with the interests of the state.

Critical analysis of scientists' approaches to the definition of the system of food security criteria allowed to establish such features of their formation in the national science:

1) the dominant criteria that form the framework for providing food security in the national economy, scientists determine according to the scientific and theoretical positions of epistemological content of the category "food security" of the country; or vice versa - the essence of the concept is formed, based on the defined criteria for achieving food security. The use of the first approach may lead to a narrowing or, conversely, a "blurring" of the term;

2) the replacement of the concepts of "components", "criteria" and "indicators" of food security which are partly replaced, which leads to further confusion in defining a system of indicators and interpreting the results of food safety monitoring;

3 ) insufficient attention is paid by scientists to the demarcation of the criteria for achieving food security at hierarchical levels: the vast majority of studies focus on the national and regional levels, while the level of households and the individual is practically not studied. As a result, the determining factors that are inherent in each level are lost.

The author's suggestions for solving these problems are the following (Fig. 2):
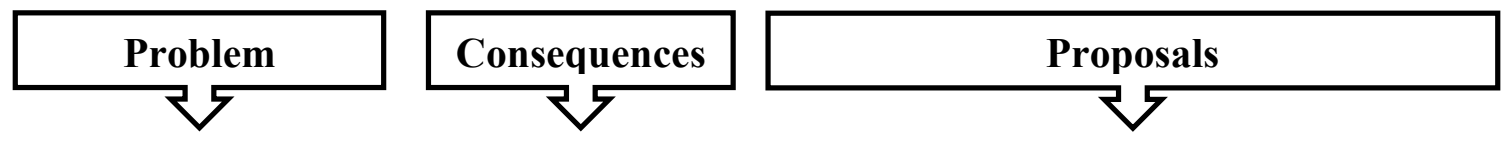


\begin{tabular}{|c|c|c|c|}
\hline 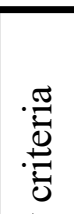 & $\begin{array}{l}\text { a dual approach to the } \\
\text { formation of the } \\
\text { criteria and the } \\
\text { essence of the concept } \\
\text { of "food security" }\end{array}$ & $\begin{array}{l}\text { can lead to a } \\
\text { narrowing or, } \\
\text { "blurring" of } \\
\text { the term }\end{array}$ & $\begin{array}{l}\text { the essence of the category to form, based } \\
\text { on the criteria for achieving food security, } \\
\text { because the latter are the tasks that } \\
\text { determine the content and goals }\end{array}$ \\
\hline 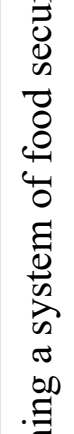 & $\begin{array}{l}\text { replacing the concept } \\
\text { of "components", } \\
\text { "criteria" and } \\
\text { "indicators" of food } \\
\text { security }\end{array}$ & $\begin{array}{l}\text { leads to } \\
\text { further } \\
\text { confusion in } \\
\text { defining a } \\
\text { system of } \\
\text { indicators and } \\
\text { interpreting } \\
\text { the results of } \\
\text { food security } \\
\text { monitoring }\end{array}$ & $\begin{array}{l}\text { components of food security - SDG2; } \\
\text { criteria - tasks of sustainable development } \\
\text { in the SDG2; } \\
\text { indicators are components that can be } \\
\text { quantified by the defined calculation } \\
\text { methodology and allow qualitative and } \\
\text { quantitative interpretation of results, } \\
\text { monitoring of food security in time and at } \\
\text { different hierarchical levels }\end{array}$ \\
\hline 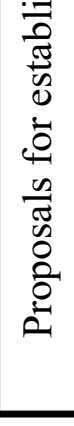 & $\begin{array}{l}\text { unclear demarcation } \\
\text { of the criteria for } \\
\text { achieving food } \\
\text { security at } \\
\text { hierarchical levels }\end{array}$ & $\begin{array}{c}\text { the } \\
\text { determining } \\
\text { determinants } \\
\text { inherent in } \\
\text { each level are } \\
\text { lost }\end{array}$ & $\begin{array}{l}\text { the global level - the achievement of the } \\
\text { SDG2; } \\
\text { national level - realization of effective agro- } \\
\text { food trade policy of the state; } \\
\text { regional level - creation of sustainable food } \\
\text { systems; } \\
\text { household - providing health to its } \\
\text { members; } \\
\text { the individual - the satisfaction of personal } \\
\text { needs }\end{array}$ \\
\hline
\end{tabular}

Figure 2. Proposals for the forming the system of food security criteria based on existing problems

1) it is advisable to use the approach, in which the essence of the concept is formed, based on the defined criteria for achieving food security. The content of the concept of "food security" is constantly evolving, which depends on tasks set for a specific period of time. Consequently, it is appropriate to form the essence of the category, based on the criteria for achieving food security, since the latter are the tasks defining the content and objectives;

2) taking into account the experience world organizations and FAO's approaches to the issue of developing a system of criteria, components and indicators of food security, it was considered to put the following content in the defined notions: food security components must comply with the SDG 2; food safety criteria should be consistent with the objectives of sustainable development in the SDG 2; indicators are components that can be quantified by the defined calculation methodology and allow qualitative and quantitative interpretation of results, monitoring of food security in time and at different hierarchical levels;

3 ) the research of the scientific and theoretical base of food security and its problems in Ukraine can help to determine the following determinants of each hierarchical level as criteria for achieving food security: the global level - the achievement of the SDG 2; national level - realization of effective agro-food trade policy of the state; regional level - creation of sustainable food systems; household - providing health to its members; the individual - the satisfaction of personal needs.

\section{Conclusions}


Critical analysis of scientists' approaches to the definition of the system of food security criteria is carried out. The methodological foundations for the formation of a system of criteria for the appropriate levels of food security in accordance with the goals of sustainable development have been systematized and deepened.

The expediency of the methodological approach, in which the essence of the concept is formed, based on the defined criteria for achieving food security, is substantiated.

The author's vision of essential content of categories is offered: criterion, component and indicator of food security.

Determinants of each hierarchical level are established as criteria for achieving food security.

\section{Acknowledgments}

This study is prepared as part of the implementation of the initiative research theme "Food security in terms of European integration of Ukraine" (the state registration number is 0114U007072). This research did not receive any specific grant from funding agencies in the public, commercial, or not-for-profit sectors.

\section{References}

Artimonova, I.V. (2016). Theoretical Approaches to the Formation of the Food Security System // Formation of market relations in Ukraine. Vol. 178: 19-23.

Babych, M.M. (2017). Conceptually-categorical essence of food security // Economy and the state. Vol. 6: 39-45.

Bruce M. Campbell, Douglas J. Beare, Elena M. Bennett, Jason M. Hall-Spencer, John S. I. Ingram, Fernando Jaramillo, Rodomiro Ortiz, Navin Ramankutty, Jeffrey A. Sayer and Drew Shindell (2017). Agriculture production as a major driver of the Earth system exceeding planetary boundaries // Ecology and Society. Vol. 22. No. (4): 11. DOI: https://doi.org/10.5751/ES-09595-220408

Christophe Béné, Steven D. Prager, Harold A. E. Achicanoy, Patricia Alvarez Toro, Brendan R. Mapes (2019). Understanding food systems drivers: A critical review of the literature // Global Food Security. Vol. 23: 149-159. DOI: https://doi.org/10.1016/j.gfs.2019.04.009

Francesca Galli, Paolo Prosperi, Elena Favilli, Simona D'Amico, Gianluca Brunori (2020). How can policy processes remove barriers to sustainable food systems in Europe? Contributing to a policy framework for agri-food transitions // Food Policy. Available online, Article 101871. DOI: https://doi.org/10.1016/j.foodpol.2020.101871

Grishova, I.Yu. and Kryukova, I.O. (2014). Current state and problems of food security of Ukraine // Bulletin of the Sumy National Agrarian University. Series «Economics and Management». Vol. 61:20-25.

Initiative of the United Nations Ad Hoc Committee «ACC / SCN». (n.d.). research.un.org. Retrieved from http://research.un.org/en/docs/ga/quick/regular/46

Jeroen J.L. Candel, Gerard E. Breeman, Sabina J. Stiller, Catrien J. A. M. Termeer (2014). Disentangling the consensus frame of food security: The case of the EU Common Agricultural Policy reform debate // Food Policy. Vol. 44: 47-58. DOI: https://doi.org/10.1016/ j.foodpol.2013.10.005

Johan van Rooyen, Howard Sigwele (1998). Towards regional food security in southern Africa: a (new) policy framework for the agricultural sector // Food Policy. Vol. 23: 491-504. DOI: https://doi.org/10.1016/S0306-9192(98)00057-8

John L. Fiedler (2013). Towards overcoming the food consumption information gap: Strengthening household consumption and expenditures surveys for food and nutrition policymaking // Global Food Security. Vol. 2: 56-63. DOI: https://doi.org/10.1016 / j.gfs.2012.09.002

Kotykova, O., Babych, M., Semenchuk, I. (2019). Monitoring of food security at the regional level // Management Theory and Studies for Rural Business and Infrastructure Development. Vol. 41. No. 4: 463-473. DOI: https://doi.org/10.15544/mts.2019.37

Kundeeva, O.I. (2013). Food security: differentiation of food supply levels of the country // Scientific works of NUKHT. Vol. 49: 139-145. 
Mostenska, T.G. (2015). Food security at the household level // Economics and social development: scientific works of NUKHT. Vol. 21. No. 1: 121-133.

Novikov, Ye. YU. (2012). Essential content of the concept of "food security" // Scientific herald of Poltava University of Economics and Trade. Vol. 2. No. 53: 47-50.

Olivier De Schutter, Nick Jacobs, Chantal Clément (2020). A 'Common Food Policy' for Europe: How governance reforms can spark a shift to healthy diets and sustainable food systems // Food Policy. Available online, Article 101849. DOI: https://doi.org/10.1016/j.foodpol.2020.101849

Ranganathan, J., Vennard, D., Waite, T., Dumas, P., Lipinski, B., Searchinger, T., GLOBAGRI-WRR model authors (2016). Shifting Diets for a Sustainable Food Future. Installment 11 of "Creating a Sustainable Food Future", Working Paper. World Resources Institute. DOI: https://doi.org/10.13140/RG.2.1.3808.2961

Sen, A. (1984). Resources, Values and Development. Oxford: Blackwell.

Site of FAO "Food Security and Food Monitoring to support the implementation of the Sustainable Development Agenda for the period up to 2030: Summaries and Future Plans". 2016. http://www.fao.org/3/a-i6188e.pdf [2019 03 04]

Site of FAO "Rome Declaration on World Food Security". 1996. Retrieved from http://www.fao.org/3/w3613e/w3613e00.htm [2019 02 01]

Strashinska, N.V. and Gretska, H.A. (2012). The main criteria for assessing Ukraine's food security level and its strategic direction. - http://dspace.nuft.edu.ua/jspui/bitstream/123456789/9841/1/ST2.pdf [2018 07 09] 